\title{
On the flood peak distributions over China
}

\author{
Long Yang ${ }^{1}$, Lachun Wang ${ }^{1}$, Xiang $\mathrm{Li}^{2,3}$, and Jie Gao ${ }^{4}$ \\ ${ }^{1}$ School of Geography and Ocean Science, Nanjing University, Nanjing, Jiangsu, China \\ ${ }^{2}$ China Institute of Water Resources and Hydropower Research, Beijing, China \\ ${ }^{3}$ State Key Laboratory of Plateau Ecology and Agriculture, Qinghai University, Xining, China \\ ${ }^{4}$ China Renewable Energy Engineering Institute, Beijing, China
}

Correspondence: Long Yang (yanglong@nju.edu.cn)

Received: 20 June 2019 - Discussion started: 12 July 2019

Revised: 25 October 2019 - Accepted: 1 November 2019 - Published: 18 December 2019

\begin{abstract}
Here we for the first time present a nationwide characterization of flood hazards across China. Our analysis is based on an exceptional dataset of 1120 stream gauging stations with continuous records of annual flood peaks for at least 50 years across the entire country. Our results are organized by centering on various aspects of flood peak distributions, including temporal changes in flood series and their spatial variations, the statistical distribution of extreme values, and the properties of storms that lead to annual flood peaks. These aspects altogether contribute to an improved understanding of flood hydrology under a changing environment over China and promote advances in flood science at the global scale. Historical changes in annual flood peaks demonstrate frequent abrupt changes rather than slowly varying trends. The dominance of decreasing annual flood peak magnitudes indicates a weakening tendency of flood hazards over China in recent decades. We model the upper tails of flood peaks based on the generalized extreme value (GEV) distributions. The GEV shape parameter is weakly dependent on drainage area, but it shows spatial splits tied to rainfall climatology between northern and southern China. Landfalling tropical cyclones play an important role in characterizing the upper-tail properties of flood peak distributions especially in northern China and southeastern coast, while the upper tails of flood peaks are dominated by extreme monsoon rainfall in southern China. Severe flood hazards associated with landfalling tropical cyclones are characterized by complex interactions of storm circulations with synoptic environments (i.e., mid-latitude baroclinic disturbances) and regional topography.
\end{abstract}

\section{Introduction}

We examine flood peak distributions over China based on 1120 stream gauging stations with continuous records of annual maximum flood peaks for at least 50 years. The ultimate goal of our study is to provide improved characterizations of flood hazards across China from both statistical and physical perspectives. This involves a comprehensive suite of analyses that investigate temporal nonstationarities in annual flood peaks (i.e., temporal distribution), flood peak distribution based on the extreme value theory (i.e., statistical distribution), and critical factors (in terms of both physiography and climate) that determine the upper tails of flood peaks (i.e., spatial distribution).

Hydrological regimes in most river basins over China, like the rest of the world, have experienced strong anthropogenic influences (i.e., river regulations and land use changes). Human-related impacts on flood hydrology are further complicated by detectable changes in external factors that are critical for flood-generation processes, such as temperature and extreme rainfall, even though it remains unsettled whether the changes are due to natural climate variability or human-induced climate change (e.g., Held and Soden, 2006; Marvel and Bonfils, 2013; Trenberth et al., 2015; Schaller et al., 2016; Risser and Wehner, 2017; Eden et al., 2018). The stationarity assumption of flood series has been questioned and debated in the scientific community (Milly et al., 2008; Montanari and Koutsoyiannis, 2014; Salas et al., 2018). Extensive studies on the stationarity of annual flood peaks have been carried out in many parts of the world (e.g., Robson et al., 1998; Robson, 2002; Franks and Kuczera, 2002; Villarini et al., 
2009; $\quad$ Petrow and Merz, 2009; Villarini et al., 2011; Ishak et al., 2013; Tan and Gan, 2014; Mediero et al., 2014; Hodgkins et al., 2019), including some efforts in global-scale investigations of historical changes in flood series (e.g., Arnell and Gosling, 2016; Do et al., 2017, 2019). Due to the limitation of observational datasets, existing knowledge on flood hazard is significantly biased towards Europe and North America, with the characteristics of other worldwide regions (including China) far from being well represented. There are some regional studies across China (e.g., Zhang et al., 2016, 2014; Zhang et al., 2018b; Liu et al., 2018). A nationwide investigation on the stationarity in flood series over China, however, is still missing. The exceptional dataset of annual flood peaks, as demonstrated in the present study, will provide additional evidence for detectable changes in flood hydrology under a changing environment. A better understanding of historical changes in annual flood peaks is of paramount importance for constraining model-based projections of flood hazards (e.g., Milly et al., 2002; Hirabayashi et al., 2013; Dankers et al., 2014; Arnell and Gosling, 2016). In this study, we expect to explore the dominant mode (i.e., abrupt changes or slowly varying trends) of nonstationarities in flood series and highlight potential factors that induce the changes in annual flood peaks.

An improved understanding of flood hazard requires essential knowledge of flood-generation mechanisms. This is also a critical aspect to consider for improved flood frequency analysis (Hirschboeck, 1988; Singh et al., 2005; Leonard et al., 2014; Brooks and Day, 2015; Yan et al., 2017, 2019). Smith et al. (2018) show that the most extreme flood peaks are frequently determined by extreme events resulting from anomalous flood agents for particular regions of the United States (which is the notion of "strange floods"). The mixture of flood-generation mechanisms poses great challenges for characterizing the upper tails of flood peaks, as different flood agents might lead to flood regimes with distinct statistics (e.g., magnitude, timing, and frequency). This is, however, often the case for many regions of the world (e.g., Jarrett and Costa, 1988; Smith et al., 2011; Villarini, 2016; Blöschl et al., 2017; Smith et al., 2018; England et al., 2018). We expect annual flood peaks over China that are characterized by a mixture of flood-generation mechanisms due to its geographic location in a monsoon climate region and on the margin of the most active ocean in tropical cyclones. China suffers the most frequent landfalling tropical cyclones in the world, with nine tropical cyclones making landfall on average per year (Jiang and Jiang, 2014). Despite its significance, little is known about the hydroclimatology of flooding associated with landfalling tropical cyclones. Even less effort has been spent on investigating the impacts of different flood-generation mechanisms on the upper-tail properties of flood peaks across China. This is a critical issue for China that shows contrasting rainfall climatology (under the combined influences of monsoons and landfalling trop- ical cyclones) between the northern and southern parts of the country (i.e., traditionally taking the Yangtze River as the geographic divide) (e.g., Yang et al., 2013; Gu et al., 2017a; Zhang et al., 2018a). Extreme floods for different regions are often associated with contrasting flood agents. This is not merely associated with the nature of flood agents themselves but is also determined by the complex interplay of storms with ambient synoptic and physiographic environments. For instance, extreme rainfall from landfalling tropical cyclones can be amplified through interactions of storm circulation with mid-latitude baroclinic disturbances (e.g., Hart and Evans, 2000) and regional topography (e.g., Houze, 2012). Propagation of monsoons also plays a role in determining the spatial contrasts of flood agents through regulating temporal occurrences of flood peaks over different regions (e.g., Ding and Zhang, 2009). Knowledge of the mixed flood-generation mechanisms and their spatial variations can provide valuable insights into improved procedures for estimating probable maximum precipitation (PMP) and probable maximum flood (PMF) values in designing flood-control infrastructure (e.g., Smith and Baeck, 2015; Yang et al., 2017).

An important way of characterizing flood hazards is by examining flood peak distributions and factors that determine the upper-tail properties. In this study, we model annual flood peaks based on the statistical framework of the generalized extreme value (GEV) distributions (similarly see e.g., Katz et al., 2002; Morrison and Smith, 2002; Villarini and Smith, 2010; Barros et al., 2014; Bates et al., 2015; Gaume, 2018; Smith et al., 2018). The key focus is placed on the upper tails of flood peaks across China. Previous studies show a strong dependence of location and scale parameters for the GEV distributions on drainage area, while the GEV shape parameters only weakly depend on drainage area (Morrison and Smith, 2002; Villarini and Smith, 2010). A weak dependence of the GEV shape parameters on drainage area indicates scale-independent properties of the upper tails of flood peaks. This highlights additional factors (e.g., spatiotemporal rainfall variability) in determining the upper tails of flood peaks. Yang et al. (2013) identified a spatial contrast of extreme rainfall distributions between northern and southern China and pointed to contrasting flood hydroclimatology across the country. We therefore propose that similar spatial contrasts also exist in flood peak distributions across China.

Our study is also motivated by Typhoon Nina and the resultant August 1975 flood in central China. The August 1975 flood in central China, with 26000 direct fatalities, is one of the most destructive floods in world history (Yang et al., 2017). The unit peak discharge is $17 \mathrm{~m}^{3} \mathrm{~s}^{-1} \mathrm{~km}^{-2}$ (i.e., flood peak discharge divided by drainage area) for a $760 \mathrm{~km}^{2}$ drainage basin, and it is on the list of the world's maximum floods. The August 1975 flood plays a key role in shaping the envelope curve of floods in China and different versions of the world envelope curve (Yang et al., 2017; Costa, 1987). The devastating consequences of Typhoon Nina and the August 1975 flood partially resulted from cascading collapses 
of dozens of dams, and they expose inadequacies of conventional approaches for flood frequency analysis (e.g., fitting historical flood records with assumed distribution functions) (e.g., Smith and Baeck, 2015; Yang et al., 2017). This is an urgent issue for China, as statistics show that socioeconomic damage caused by tropical cyclones has been rapidly increasing in recent decades, with a large portion of the damages resulting from riverine flooding (Zhang et al., 2009; Rappaport, 2014).

Based on the aforementioned gap in our knowledge in flood hydrology, we examine flood peak distributions across China by centering on the following questions:

1. What is the dominant mode of the violation of stationarity in annual flood peak series?

2. How do dominant flood-generation mechanisms vary across China?

3. How do upper-tail properties of flood peak distributions depend on drainage areas (i.e., scale dependence) and rainfall climatology?

4. What is the impact of landfalling tropical cyclones on the upper tails of flood peaks across China?

5. What are the characteristics of the most severe flood hazards (i.e., as represented by the number of stations with annual flood peaks) in the history of China and the tropical cyclones that induce them?

Even though these questions are examined based on an exclusive dataset over China, timely answers to these questions will undoubtedly contribute to complementing our limited understanding of flood hazards in a changing environment and promote the advance of flood science at the global scale.

\section{Data}

Our analysis is based on observations of annual maximum instantaneous peak discharge from 1120 stream gauging stations with continuous records of at least 50 years (i.e., no missing data consecutively throughout the entire periods). There are relatively more stations distributed in eastern China than the western part of the country (Fig. 1). The dataset is comprehensively collected from the local hydrographic offices of nine major river basins across China. All these stations are nation-level control stations with records that have been through strict quality control procedures to ensure data consistency and accuracy (by following the code for hydrologic data compilation of China, SL247-1999). Stations with notable site relocations (i.e., that lead to changes in drainage area) during the observational periods are not included in this dataset. The flood records demonstrate a variety of data collection methods, mainly including intermittent direct measurements of discharge during flood seasons, indirect inferences through stage-discharge rating curves, and post-flood

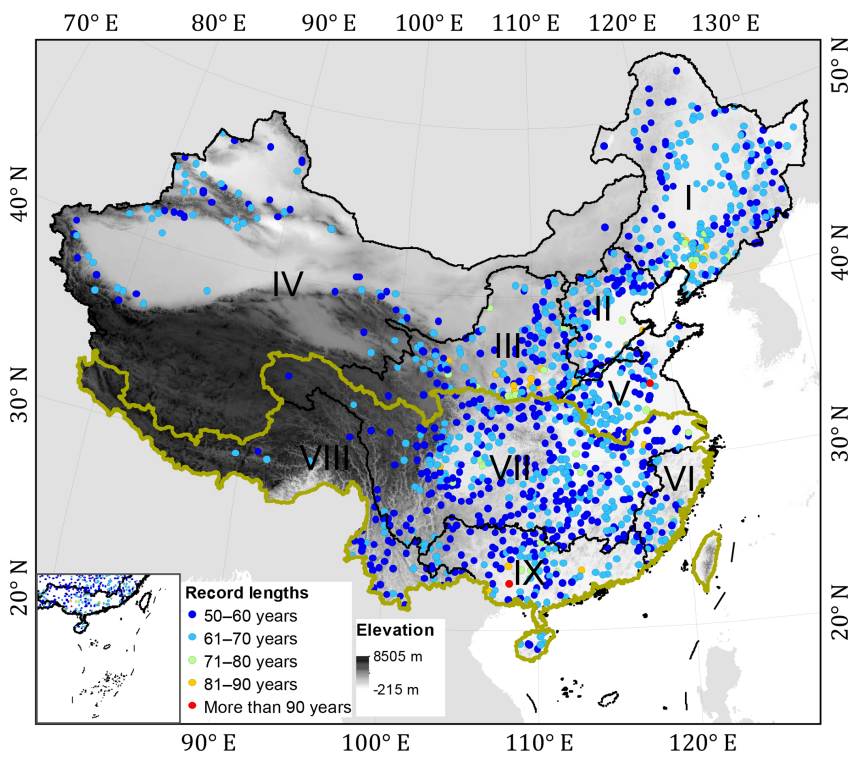

Figure 1. Overview of the stream gauging stations with record lengths of more than 50 years over China (1120 gauges in total). Scatter shading represents the record length (in years) for each station. The grey shading represents topography, while the black lines represent the first-level hydrologic units. The Roman numerals highlight the nine major hydrologic units in China: I northeastern river basins, II Hai He basin, III Yellow River basin, IV northwestern river basins, V Huai He basin, VI southeastern river basins, VII Yangtze River basin, VIII southwestern river basins, and IX Pearl River basin. Olive line shows the boundary of river basins in southern China (VI-IX) with the rest of the river basins in northern China (I-V).

field surveys. In addition to flood peak magnitude, flood peak timing (i.e., date of occurrence for flood peaks) is also provided, and this is mainly used to infer flood-generating mechanisms over different regions across China. Flood records with missing flood peak timing values are discarded from the following analysis.

Time series of the total number of available stations are shown in Fig. 2a. The longest flood record is 153 years, with approximately more than $90 \%$ stations fully available during the period from 1960 to 2017. The record length of $66 \%$ stations exceeds 60 years starting in 1950s and continuing until the year 2017 (Fig. 2b). There are considerable variations in the spatial scales of the represented river basins, with a large percentage (approximately $64 \%$ ) of the stations representing small and medium river basins (with drainage areas less than $5000 \mathrm{~km}^{2}$, Fig. 2c). Previous studies found contrasting climate regimes and extreme rainfall distributions between northern and southern China (e.g., Yang et al., 2013; Ma et al., 2015). To facilitate analyses and comparisons, we further classify the 1120 stations into two sub-groups, i.e., northern and southern China, based on their geographic locations (Fig. 1). The northern group includes stations mainly in northeastern river basins, the Yellow River basin, the Huai 

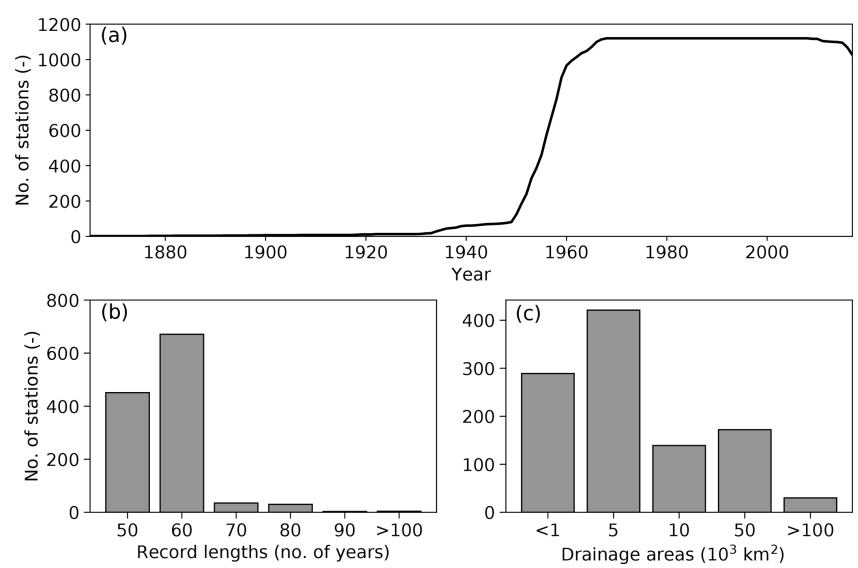

Figure 2. (a) Time series of the total number of available stations (with record lengths of more than 50 years) for each year. Histograms of all the 1120 stream gauging stations sorted by (b) record lengths and (c) drainage areas.

He basin, and the Hai He basin, while the southern group includes southeastern river basins, southwestern river basins, the Yangtze River basin, and the Pearl River basin.

\section{Methodology}

\subsection{Change point and trend analysis}

We use the non-parametric Pettitt's test (Pettitt, 1979) to examine the presence of abrupt changes in the annual flood peak series. Pettitt's test is a rank-based test that relies on the Mann-Whitney statistic to test whether two samples come from the same population. There are no assumed distributions for the test, which makes it less sensitive to outliers and skewed distributions. It allows for the detection of a single change point in mean at an unknown point in time, with the test significance computed using the given formulation. We further apply the Pettitt's test on the squared residuals derived with respect to the local polynomial regression line (LOESS (locally estimated scatterplot smoothing) function, Cleveland, 1979) to detect the change point in variance in the annual flood peak series (similarly see, e.g., Villarini et al., 2009; Villarini and Smith, 2010; Yang et al., 2013). We also adopted a different change-point detection approach, i.e., the one proposed by Matteson and James (2014), but we only found negligible deviations from the results based on Pettitt's test (results not shown).

Monotonic trends can be induced by the existence of abrupt change points in mean rather than indicating slowly varying trends for the flood series. For those series that do not show significant abrupt change points in mean, we directly use the non-parametric Mann-Kendall test (Mann, 1945; Kendall, 1975) to examine the presence of monotonically increasing or decreasing trends in annual flood peak series. We divide the series with change points in mean into two sub-groups and test monotonic trends for each of the two sub-groups (i.e., before and after the change point). Additional trend analysis for the subseries can highlight stations that show both abrupt changes and slowly varying trends in the entire flood series. We assume the existence of only a single change point in mean for each flood peak series in this study to avoid dividing the series into too many segments (similarly see, e.g., Villarini et al., 2009, 2012). Only subseries with record lengths exceeding 10 years are considered in the trend analysis. We set a significance level of $5 \%$ (i.e., two-tailed) for both the change-point and trend tests.

\subsection{Generalized extreme value distribution}

The generalized extreme value distribution is used to statistically model distributions of annual maximum flood peaks (e.g., Coles, 2001; Villarini and Smith, 2010). The GEV, based on the extreme value theory, has been widely used in flood frequency analysis (e.g., Coles, 2001; Katz et al., 2002; Morrison and Smith, 2002; Villarini and Smith, 2010). The cumulative distribution function of the GEV takes the form

$F(x \mid \mu, \sigma, \xi)=\exp \left\{-\left[1+\xi\left(\frac{x-\mu}{\sigma}\right)\right]^{-1 / \xi}\right\}$,

where $\mu, \sigma$, and $\xi$ represent the location, scale, and shape parameter, respectively. The location $(\mu)$ and scale $(\sigma)$ parameters are related to the magnitude and variability of the records, respectively. The shape parameter $(\xi)$ indicates the tail properties of the distribution, with positive (negative) values pointing to the heavy and unbounded (light and bounded) upper tail of the flood peak distribution. The GEV parameters are estimated based on the maximum likelihood estimators (e.g., Coles, 2001). We fit the GEV distributions only for stations without statistically significant change points in mean and variance and monotonic trends, following the basic assumption of probability theory that data samples should be independent and identically distributed. The three fitted GEV parameters (i.e., location, scale, and shape) will be further used to examine their correlations with drainage areas, shedding light on the scale dependence of the upper-tail properties of flood peak distributions across China.

\subsection{Association of flood peaks with tropical cyclones}

We associate an annual flood peak of a given stream gauging station with a particular tropical cyclone by following the procedures, i.e., if the center of a tropical cyclone is within $500 \mathrm{~km}$ of the gauging station during a time window of two weeks centered on the occurrence time of the flood peak. The spatial and temporal thresholds reflect the mean spatial extent of tropical-cyclone rainfall (e.g., Rios Gaona et al., 2018) and the upper limit of flood response time (similarly also see, e.g., Hart and Evans, 2000; Villarini and Smith, 2010; Smith et al., 2011; Villarini et al., 2014). We obtain the information of tropical cyclones from the In- 
ternational Best Track Archive for Climate Stewardship (IBTrACS, see https://www.ncdc.noaa.gov/ibtracs/, last access: 20 April 2019, for details). The dataset provides records of the circulation center location (latitude and longitude) and storm intensity (represented by minimum sea level pressure) at a temporal interval of $6 \mathrm{~h}$. An additional attribute provided by IBTrACS for each tropical cyclone at each time interval is the nature of the storm, i.e., an extratropical transition or tropical storm. Extratropical transition (ET) characterizes the changing properties of a tropical cyclone from a warm-core, symmetric structure to a cold-core, asymmetrical structure (e.g., Hart and Evans, 2000). Physical processes associated with an extratropical transition play an important role in determining the spatial distribution of tropical-cyclone rainfall (e.g., Atallah and Bosart, 2003; Atallah et al., 2007; Liu and Smith, 2016). Tropical storm (TS), by contrast, indicates the maintenance of a warm-core, symmetric structure during the entire life cycle of the storm.

\section{Results and discussion}

The structure of this section is organized as follows. We first detect change points and monotonic trends to shed light on the long-term changes in flood series across China and discuss possible drivers that induce them (Sect. 4.1). We move on to Sect. 4.2 to examine the seasonal distribution of annual flood peaks, highlighting the mixture of flood-generation mechanisms across China and its spatial variation. Results from both Sect. 4.1 and 4.2 will serve as the basis for the analysis of Sect. 4.3 that delves into the upper-tail properties of flood peak distributions across China, focusing on the spatial distributions of the GEV parameters as well as their dependence on drainage areas and rainfall climatology. Section 4.4 will specifically examine the impacts of tropical cyclones on extreme floods to shed light on the statistical and physical characteristics of the most extreme floods in the history of China.

\subsection{Stationarity}

\subsubsection{Abrupt changes}

Figure 3 shows the results of change-point analyses for annual flood peaks based on Pettitt's test. There are $436(38 \%)$ and $398(35 \%)$ stations with significant change points in mean and in variance, respectively; $27 \%$ of the stations show change points both in mean and in variance. The majority of the stations tend to show smaller values in mean (383 stations) and variance (305 stations) after compared to before the change point (figure not shown). Change points in both mean and variance show striking spatial concentration in northern China (i.e., the lower Yellow River basin, the upper Huai He basin, and the entire Hai He basin). Change points in both mean and in variance are frequently observed during the period 1980-2000, with a slightly larger frequency of occur-

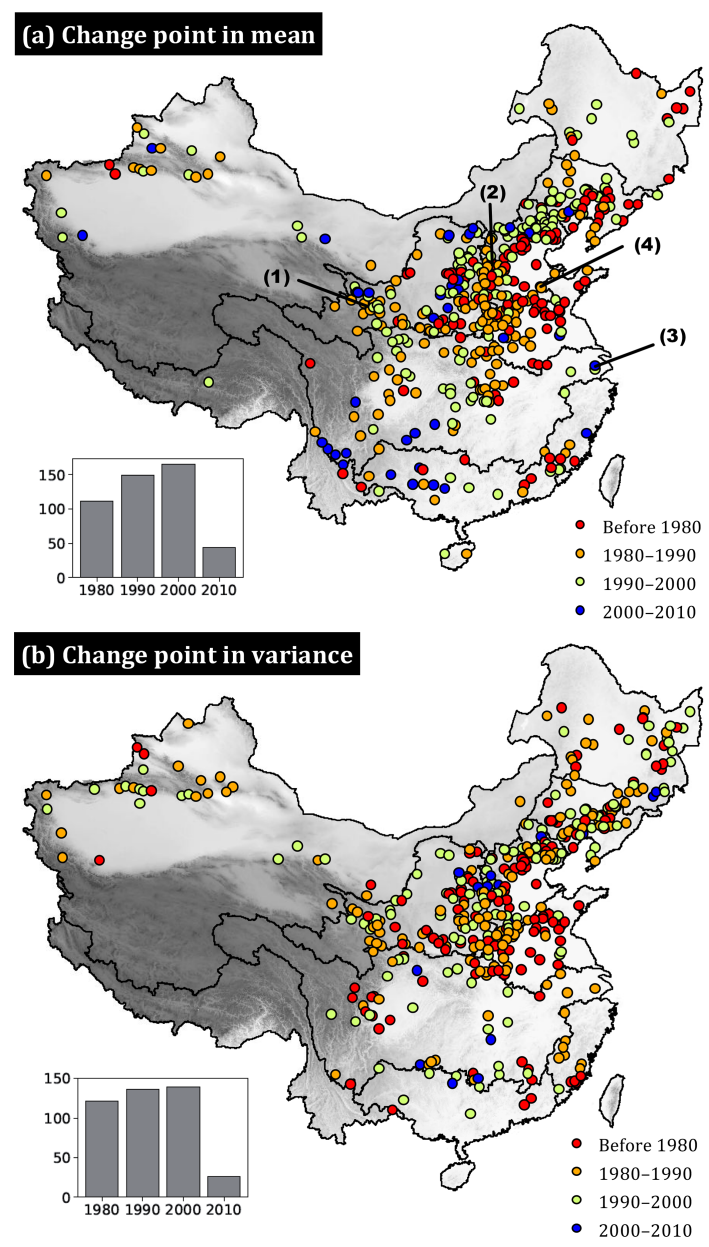

Figure 3. Change points in (a) mean and (b) variance. Color represents the year of the change-point occurrence. The insert plot shows the histogram of the years of the change-point occurrence (the $y$ axis represents the number of change points, while the $x$ axis represents the ending year of a 10-year period; e.g., 1990 actually means 1980-1990). Only stations with results being statistically significant (at the level of $5 \%$ ) are shown. There are $436(38 \%)$ and $398(35 \%)$ stations with significant change points in mean and in variance, respectively.

rence during the period 1990-2000. We observe an additional number of change points in mean distributed downstream of the southwestern river basins and in the upper and middle portion of the Yangtze River and Pearl River basins (Fig. 3a). These change points tend to occur in the period 2000-2010 instead of the period of dominant change-point occurrence in northern China.

Spatial and temporal clustering of change points demonstrate evidence of anthropogenic influences on flood hydrology (e.g., Vogel et al., 2011; Hodgkins et al., 2019). Through metadata inspection of selected stations, we are able to relate some of the abrupt changes in annual flood peaks to intentional human activities. For instance, the change point in mean in 1986 in the upper Yellow River, at the 
Guide hydrological station, is due to the construction of a large hydropower-generation dam, the Longyangxia Dam (Fig. 4a). The Longyangxia Dam is a multi-purpose dam (e.g., flood control and water supply). It controls runoff variability in the whole of the Yellow River basin (Si et al., 2019). The Guide station is approximately $30 \mathrm{~km}$ downstream of the Longyangxia Dam. There are a couple of other hydrological stations distributed further downstream (e.g., Xunhua hydrological station, $120 \mathrm{~km}$ downstream), and these show change points in mean around the year 1986 for the annual flood peak series. Anthropogenic regulations on rivers in northern China (especially the middle and lower portions of the Yellow River basin and the upper Hai He basin) are often characterized by cascade construction of small reservoirs. We show a flood peak series in the upper Hai He basin that experienced a significant decrease in annual maximum flood peak magnitudes (smaller values both in mean and variance after the change point) around the early 1990s, associated with extensive construction of small reservoirs due to an increased demand for irrigation and domestic water supply (Fig. 4b). The impact of dam or reservoir regulation on flood hydrology has been discussed and debated in previous studies (e.g., Yang et al., 2008; Barros et al., 2014; Zhang et al., 2015; Ayalew et al., 2017; Lu et al., 2018). For instance, Smith et al. (2010) found limited impacts of dams on flood hydrology in the Delaware River basin, which is not the case for the upper Yellow River basin in our study. This might be related to contrasting physiographic properties of the river basins and/or functions of the dams, and this needs further analysis.

Changes in land use or land cover (e.g., urbanization and deforestation and/or afforestation) can also contribute to change points in the series of annual flood peaks. This is especially the case for stations in the lower Hai He basin (where the Beijing-Tianjin-Hebei metropolitan region is distributed) and the Yangtze River Delta region (where Shanghai and other major cities are located). Figure $4 \mathrm{c}$ shows a small urban watershed in the lower Yangtze River basin) that experienced rapid urbanization in recent decades. A transboundary water-transfer project demonstrates another form of anthropogenic influence on flood hydrology. Abrupt increases in flood peak magnitudes are mainly tied to the elevated base flows transferred from neighboring river basins. We provide the annual flood peak series for a station in the lower Yellow River basin (Fig. 4d). Increasing water demand from domestic and agricultural sectors in the lower Yellow River basin lead to an extensive implementation of watertransfer projects.

Abrupt changes in the series of annual flood peaks can also originate from the changes in extreme rainfall across China. However, one of our previous studies investigated changes in annual maximum daily rainfall over China, but it found no clear signature of spatial clustering for change points in either mean or variance for the rainfall series, although abrupt changes in annual maximum daily rainfall frequently occurred in the 1990s (see Fig. 2 in Yang et al., 2013). Inconsis- tent spatial patterns of change points in the annual maximum flood peak and annual maximum daily rainfall series indicate a weak role of climate shifts in producing abrupt changes in annual flood peaks.

\subsubsection{Monotonic trends}

We further examine the monotonic trends of annual flood peak series based on the Mann-Kendall test for those stations that do not show significant change points in mean. There are only 69 stations (accounting for approximately $6 \%$ of the total stations) with significant linear trends (Fig. 5a). For those stations with significant linear trends, 62 (7) of them exhibit decreasing (increasing) trends. The 62 stations are uniformly distributed across the entire country, indicating a weakening tendency of annual maximum flood peaks over China in recent decades. Abrupt changes rather than slowly varying trends are a common mode of violation of the stationarity assumption of the annual flood peak series over China. For those stations with significant change points in mean, we test the linear trends for each subseries of flood peaks before and after the change point. Almost all stations show decreasing trends for the subseries either before or after the change point with only a few exceptions (Fig. $5 \mathrm{~b}$ and c). Similar with change points in mean and in variance, stations with significant decreasing trends after change points spatially concentrate in northern China, especially the middle and lower portion of the Yellow River basin and the upper Hai He basin. The decreasing trend in the middle and lower portions of the Yellow River is most likely due to the implementation of soil conservation practices in its tributary regions (e.g., Bai et al., 2016). There are few stations in southern China that show significant linear trends either before or after change points.

Changes in annual rainfall extremes (i.e., annual maximum daily rainfall) show a "dipole-like" spatial structure over China, with decreasing trends in northern China and increasing trends in the south (e.g., Yang et al., 2013; Ma et al., 2015; Gu et al., 2017b). The decreasing annual maximum flood peaks in northern China may be partially attributed to the weakening rainfall intensity in recent decades. The opposite trends in annual rainfall extremes and annual maximum flood peaks in southern China seem contradictory to our perception. Contrasting trends between intense rainfall and annual high flows are also found over the United States (mainly eastern of the Mississippi River), which are attributed to inconsistent changes of intense rainfall in different seasons (Small et al., 2006); i.e., changes in fall precipitation mainly contribute to the trend in annual rainfall extremes, while annual high flows are often observed in spring with no significant changes in rainfall. This is, however, not the case for southern China. Changes in rainfall extremes among all four seasons are dominated by significant or relatively weak increasing trends over southern China (Gu et al., 2017b). Disconnections between changes in annual maximum rainfall and annual flood peaks are also identified in other previous 

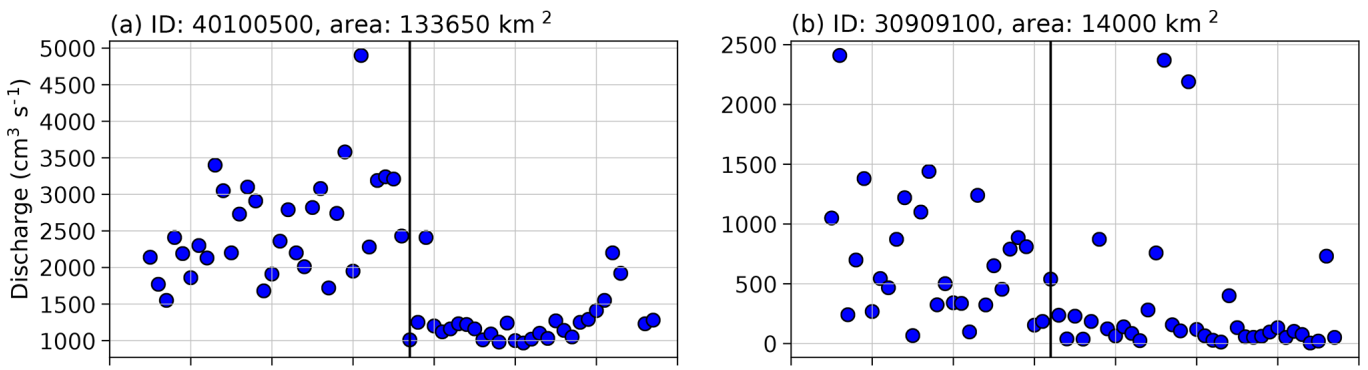

(c) ID: 63205400 , area: $334 \mathrm{~km}^{2}$
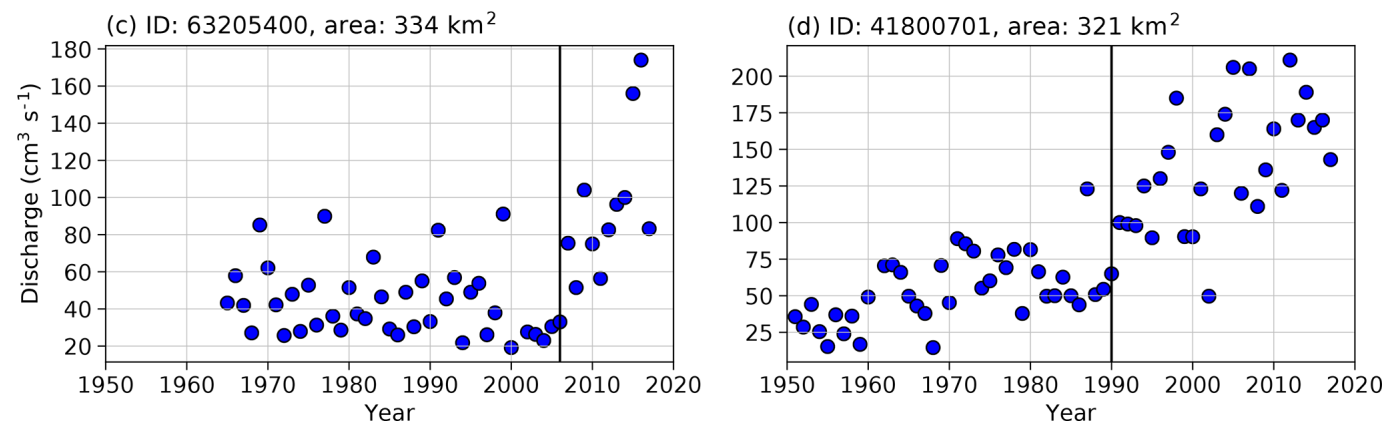

Figure 4. Time series of annual flood peaks for four stream gauging stations with strong human interventions: (a) large hydroelectric dams (upper Yellow River, ID: 40100500), (b) a cascade of small reservoirs (upper Hai He, ID: 30909100), (c) urbanization (a tributary in the lower Yangtze River, ID: 63205400), and (d) a transboundary water-transfer project (a tributary in the lower Yellow River, ID: 41800701). Locations of the four stations are represented by the numbers in brackets in Fig. 3, with (1) to (4) corresponding to (a-d), respectively. Black lines indicate the year of the occurrence for the change point in mean. Results are based on Pettitt's test. Only shown are stations with statistically significant Pettitt's test results (at the level of $5 \%$ ).

studies (e.g., Ivancic and Shaw, 2015; Berghuijs et al., 2016; Wasko and Nathan, 2019), and these point to the additional roles of antecedent watershed wetness and changes in spacetime rainfall properties in dominating flood-generation processes (i.e., storm extent, Sharma et al., 2018). Disconnection of changes in rainfall extremes and floods as exhibited for the gauges across southern China highlight the complex drivers for flood-generation processes, and this merits further investigation.

\subsection{Mixture of flood-generation mechanisms}

Long-term changes in annual flood peak series highlight the need for a better understanding of flood-generation mechanisms across China, which can be pursued through the examination of the seasonal distribution of annual flood peaks. There are three (two) distinct peaks in the seasonal distribution of annual flood peaks for southern (northern) China (Fig. 6). The first peaks for both southern and northern China occur around late April, but these result from different flood-generation mechanisms. Frequent occurrences of annual flood peaks around late April in southern China are observed mainly in the southeastern coast, and these are caused by frontal systems or associated with an early onset of the East Asian summer monsoon (e.g., Ding and Chan, 2005; Ding and Zhang, 2009). The April peak of flood frequency in northern China is contributed by localized storm events associated with mid-latitude weather systems in the northwestern part of the country or related to snowmelt in high-altitude regions (Ding and Zhang, 2009). The East Asian summer monsoon onsets around early May over mainland China, and it moves stepwise northward/northeastward driven by the western Pacific subtropical high (e.g., Ding and Chan, 2005; Zhang et al., 2017). The monsoon system is characterized by "two abrupt northward jumps and three stationary periods", and it plays a deterministic role in the seasonal distribution of flood peaks in both northern and southern China. Frequent flood peaks around late June in the middle and lower portion of the Yangtze River basin contribute to the second peak of seasonal distribution of flood frequency in southern China. Further northward propagation of the monsoon system leads to frequent annual flood peaks in northern China around late July and early August. The summer monsoon retreats back to the south and is weakened afterwards, transferring the dominance in flood-generation systems to tropical cyclones and post-monsoon synoptic systems.

Annual flood peaks that are caused by tropical cyclones show a very sharp seasonal distribution, with $70 \%$ of them observed in August alone (Fig. 6, see Sect. 3 for the association of annual flood peaks with a tropical cyclone). Strong pressure gradients along the western flank of the western Pacific subtropical high provide favorable synoptic conditions for large-scale moisture transport and northwestward propagation of tropical cyclones. Interactions of tropical cyclones with mid-latitude systems (e.g., mid-latitude upper- 

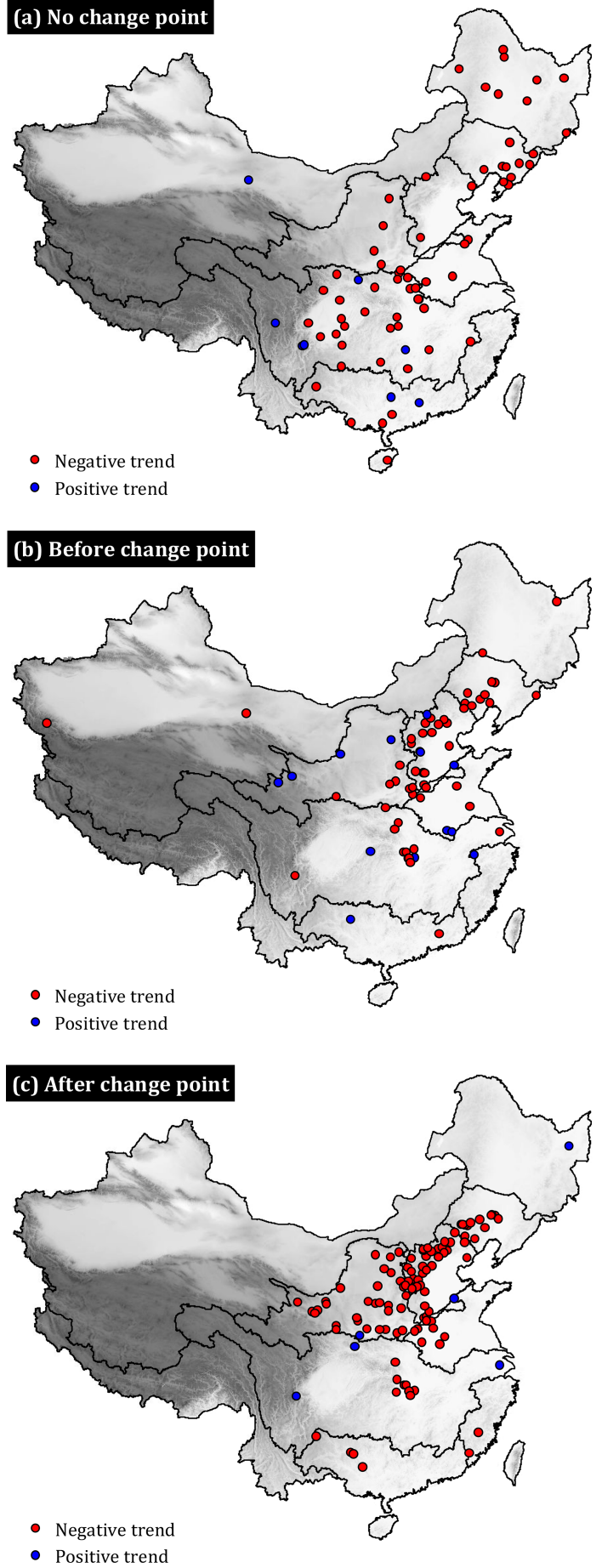

Figure 5. Mann-Kendall test results for stations (a) without a change point in mean and $(\mathbf{b}, \mathbf{c})$ with a change point in mean. Results are statistically significant at the level of $5 \%$. A different number of data points between (b) and (c) are associated with (1) insufficient record lengths (e.g., less than 10 years) for sub-groups before or after change points and (2) linear trends for either sub-group not being statistically significant.

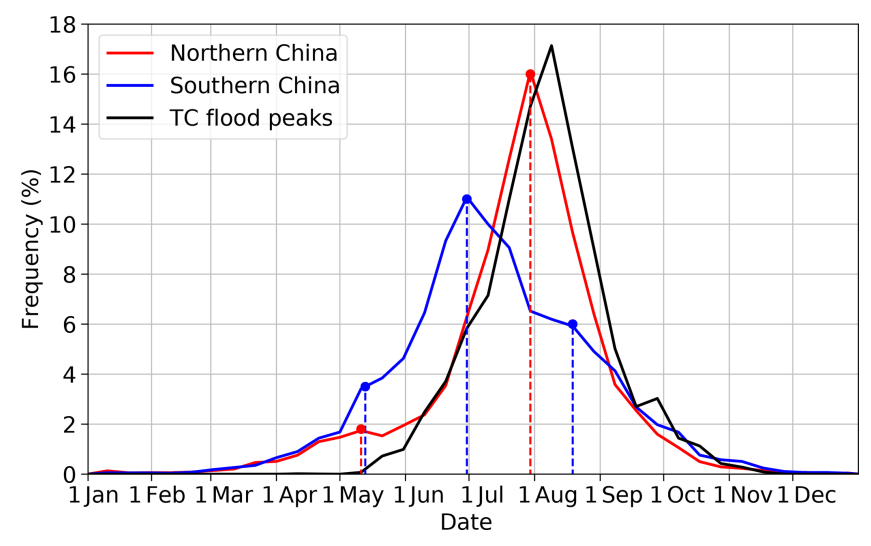

Figure 6. Seasonality of annual maximum flood peaks for northern China (red), southern China (blue), and annual flood peaks caused by tropical cyclones (black). The vertical dashed lines represent peaks of flood frequency for southern (blue) and northern China (red). In this figure, TC is used an abbreviation for tropical cyclone.

level trough) and regional topography (i.e., Qinling and Taihang Mountains) can further enhance extreme rainfall associated with landfalling tropical cyclones and the resultant flooding over China (mainly the eastern part of the country, e.g., Svensson and Berndtsson, 1996; Yang et al., 2017; Gu et al., 2017a). The seasonal distribution of annual flood peaks in northern China is almost overlapped with that of flood peaks caused by tropical cyclones, while tropical cyclones mainly contribute to the third peak of the seasonal distribution for annual flood peaks in southern China (Fig. 6). The concurrency of monsoon-controlled storm events and tropical cyclones is a key element of flood hydroclimatology across China. Analysis of the seasonal distribution of annual flood peaks highlights contrasting rainfall climatology between northern and southern China as well as the mixture of flood-generation mechanisms across the entire country.

\subsection{Extreme value distribution}

We model distributions of annual flood peaks using the GEV distribution. We only focus on the stations without significant change points in mean or in variance and without significant monotonic trends (i.e., the stationary stations). There are 486 stations that satisfy these requirements. These stations are densely located in southern rather than northern China (Fig. 7), mostly due to the spatial clustering of stations with abrupt change points in annual flood peaks in northern China (Fig. 3). The stationary stations represent a wide range of spatial scales of drainage basins for both northern and southern China. Figure 8 shows the dependence of GEV parameters on drainage area for the 486 stationary stations. Location and scale parameters are positively correlated with drainage area in a $\log -\log$ domain. The correlations are all significant at the level of $5 \%$. The shape parameter, however, generally decreases with drainage area but shows only a weak de- 


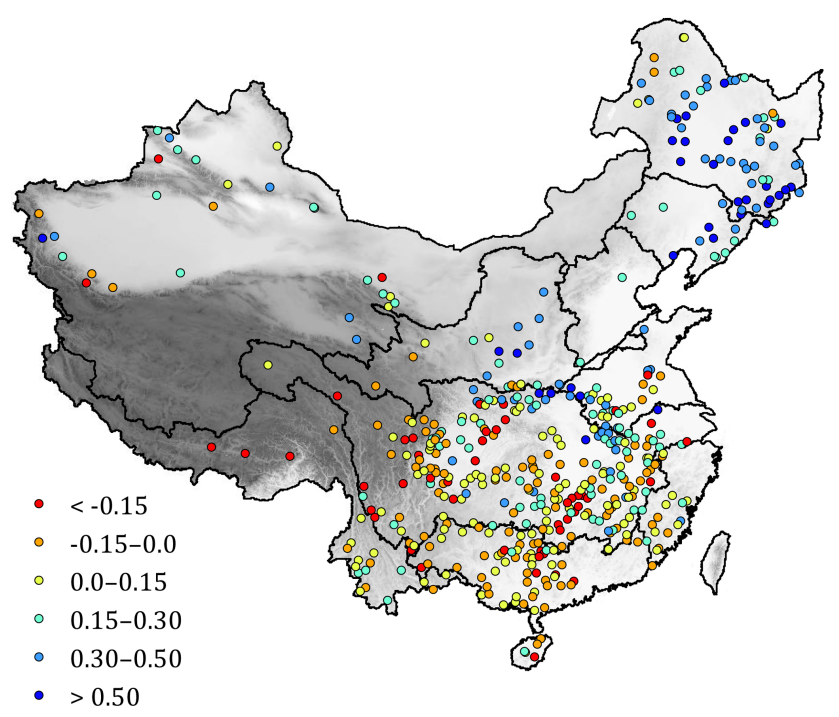

Figure 7. Map of the GEV shape parameters for the stationary time series (i.e., no significant change points in mean or in variance or monotonic trends) of annual flood peaks.

pendence in a log-log domain (with a correlation coefficient of -0.15 for northern China and -0.16 for the south, neither being statistically significant). The upper-tail properties (as represented by the shape parameter) of flood peak distributions are weakly determined by drainage areas, while the magnitude and variability of annual flood peaks can be well explained by drainage area. Our results are consistent with the study in the eastern United States by Villarini and Smith (2010), and they contribute to a generalized understanding of the upper-tail properties of flood peak distributions.

An interesting finding is that there are striking spatial splits in terms of the dependence of the GEV parameters on drainage areas between northern and southern China (Fig. 8). The location and scale parameters for stations in southern China are consistently larger than their counterparts in the north (with a few exceptions, Fig. 8a and b). The shape parameters in northern China are comparatively larger than those in southern China. Large shape parameters indicate heavier upper tails of flood peak distributions in northern than southern China, even though the magnitudes and variability of flood peaks are relatively smaller in the north. One of our previous studies on the distribution of annual maximum daily rainfall found similar spatial splits for the dependence of GEV parameters on elevation between northern and southern China (Yang et al., 2013; Gu et al., 2017a). Spatial splits in extreme rainfall distributions highlight spatial heterogeneity in flood hydroclimatology across China (which is also represented by the contrasting seasonal distributions of annual flood peaks shown in Sect. 4.2). Spatial contrasts of extreme rainfall distribution further lead to different relationships between three GEV parameters and drainage areas
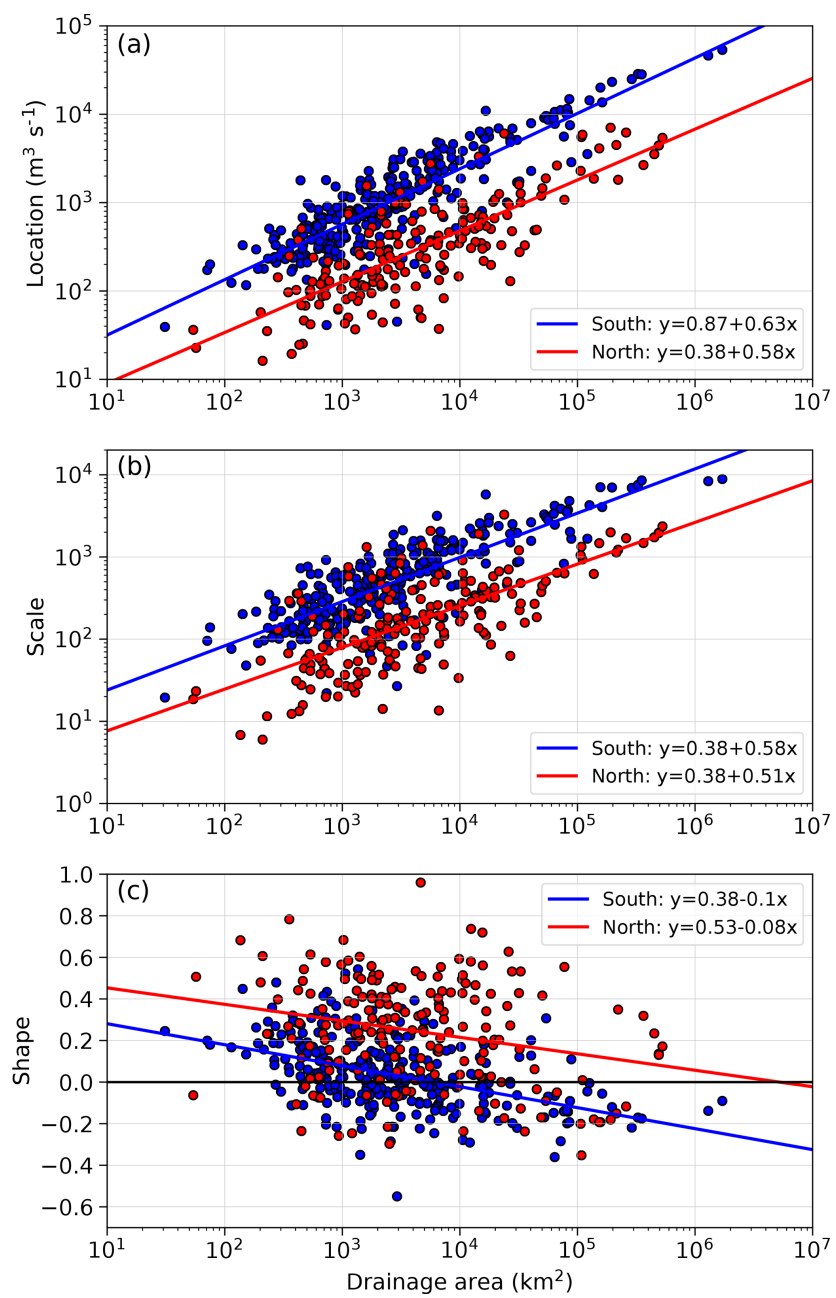

Figure 8. Scatterplots of the GEV parameters (a) location, (b) scale, and (c) shape as a function of drainage areas. Blue (red) scatters represent stations over south (north) China.

for flood peak distributions between northern and southern China.

We further show the spatial splits for the shape parameter in Fig. 7. The majority of the northern stations show positive shape parameters, while the southern stations are mixed with both negative and positive shape parameters. Spatial contrast in rainfall climatology between northern and southern China seems to be a more effective predictor in explaining the spatial variability of the shape parameter rather than drainage area. Our results highlight the importance of hydrometeorological analyses for better characterizations of the physical processes that lead to the most extreme floods (similarly see e.g., Smith and Baeck, 2015; Yang et al., 2017). Positive shape parameters in northern China indicate flood peak distributions with unbounded upper tails, while negative shape parameters for most southern stations are characterized by a bounded upper tail of flood peak distribution. Our understanding remains poor pertaining to the nature of 
the upper tail of flood peaks (see detailed discussion in, e.g., Smith et al., 2018). The bounded upper tail of flood peaks in the south can be associated with physical constrains over drainage basins (for instance, large dams for flood-control purposes) and/or the upper bounds of the hydrometeorological processes (e.g., Enzel et al., 1993; O'Connor et al., 2002; Serinaldi and Kilsby, 2014).

\subsection{Tropical cyclones and upper tails of flood peaks}

We examine the impacts of tropical cyclones on the uppertail properties of flood peak distributions across China in this subsection. As mentioned in previous sections, some of the most extreme floods in the history of China are associated with landfalling tropical cyclones in the western North Pacific basin (e.g., Typhoon Nina). Better characterizations of tropical cyclones and flood hazards associated with them can provide physical insights into the upper-tail properties of flood peak distributions.

Tropical cyclones contribute to approximately $18 \%$ of annual flood peaks over China. Figure 9 shows the map of the percentage of annual flood peaks that are caused by tropical cyclones compared to total annual flood peaks for each station. More than $50 \%$ of the annual flood peaks are caused by tropical cyclones in the southeastern coast of China, with the percentage even attaining $90 \%$ over Hainan Island. The percentage gradually decreases when we move further inland and to higher latitudes. Less than $10 \%$ of annual flood peaks can be associated with landfalling tropical cyclones in the middle portion of the Yellow River and Yangtze River basins (Fig. 9). The percentage of annual flood peaks caused by tropical cyclones is closely tied to the spatial distribution of tropical-cyclone rainfall and frequency of tropical-cyclone occurrences over China (Wu et al., 2005; Ren et al., 2010; Gu et al., 2017b). More than $30 \%$ of the extreme rainfall events are induced by tropical cyclones along the coastal regions (Gu et al., 2017a, b), with the percentage gradually decreased moving inland due to the rapid weakening of storm intensity (e.g., surface roughness and insufficient moisture transport).

We show the stations with record floods (i.e., the largest flood peak for the entire record of a station) that are caused by tropical cyclones in Fig. 9 to highlight the impact of tropical cyclones on the most extreme floods. Stations with record floods caused by tropical cyclones are spatially clustered on the southeastern coast and in central and northeastern China (Fig. 9). Tropical-cyclone-induced record floods on the southeastern coast are mainly associated with abundant moisture and an energy supply which cause extreme rainfall right after the tropical cyclones make landfall. However, the spatial clustering of record floods by tropical cyclones in northern China (more specifically, the upper Huai He and northeastern China) can be partially related to extratropical transition processes during the life cycle of the storm and/or interactions with regional topography, as will be elaborated below. We do not observe a comparable distribution of

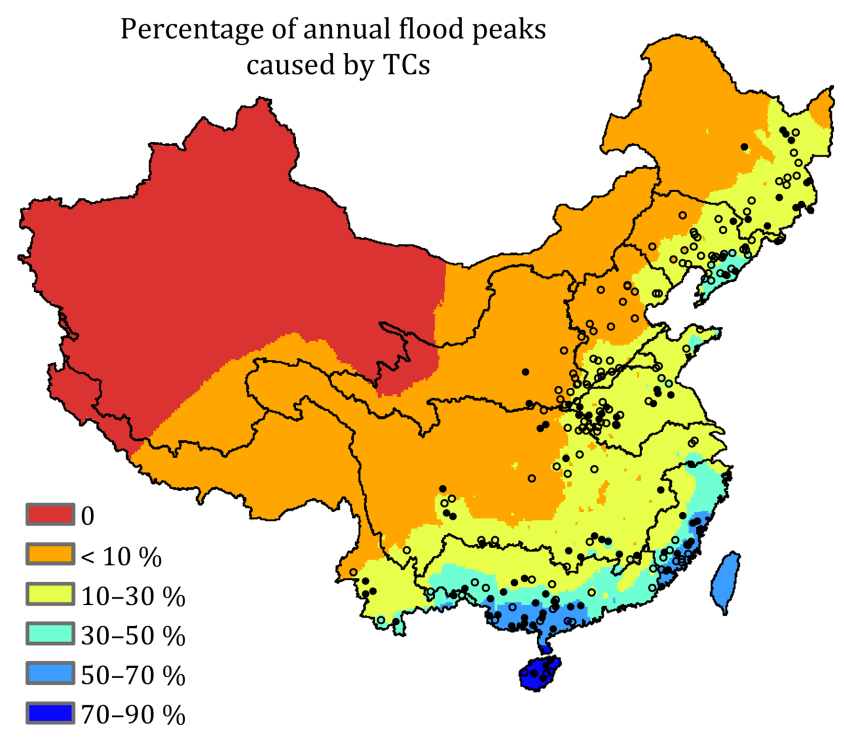

Figure 9. Percentage of annual flood peaks that are caused by tropical cyclones. The black dots and circles represent the stations with record floods caused by tropical cyclones. The black dots further highlight stations with stationary time series of annual flood peaks. In this figure, TC is used an abbreviation for tropical cyclone.

record floods caused by tropical cyclones in southern China (e.g., the Yangtze River basin) excluding the coastal regions, even though the percentage of annual flood peaks caused by a tropical cyclone is comparable to that in northern China (less than $30 \%$, Fig. 9). Our results highlight the impacts of tropical cyclones on flood peak distributions in northern China with a large percentage of record floods caused by relatively infrequent visits of landfalling tropical cyclones.

The impact of tropical cyclones on the upper-tail properties of flood peak distributions is further examined through the shape parameter of the GEV distribution. We compare the shape parameters between the entire annual flood peak series and the series with annual flood peaks caused by tropical cyclones removed (Fig. 10). We focus on the series with a record length exceeding 30 years after annual flood peaks caused by tropical cyclones are removed from the series. This leads to the exclusion of most stations on the southeastern coast due to the high percentage of tropical-cycloneinduced flood peaks (Fig. 9). As can be seen in Fig. 10, the scatters are generally distributed along the $1: 1$ line, indicating overall small changes in the shape parameters between two series. However, if we restrict our attention to the stations with record floods caused by tropical cyclones (mainly those stations in northern China), we observe significantly smaller shape parameters (see the insert box plot in Fig. 10) for the series with annual flood peaks caused by tropical cyclones removed. A smaller shape parameter implies a lighter tail of flood peak distribution. Small variations in the shape parameters as demonstrated for the rest of the stations indicate relatively weak impacts of tropical cy- 


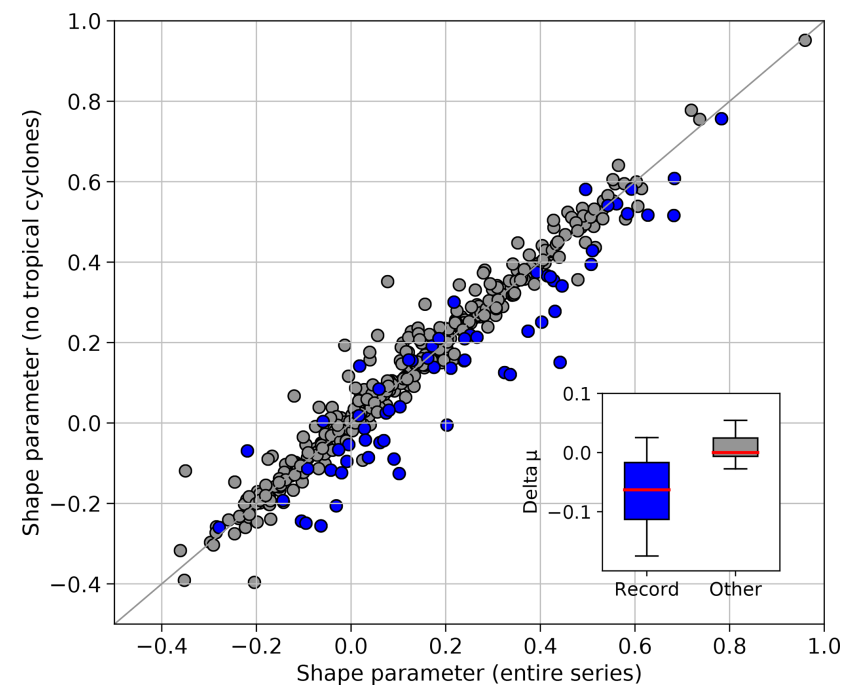

Figure 10. Scatterplot of the shape parameters for the entire series versus the series with annual flood peaks caused by tropical cyclones removed. Blue dots highlight the stations with record floods that are caused by tropical cyclones (see Fig. 1 for locations). The insert boxplot shows the differences of the shape parameter (series with tropical-cyclone flood peaks removed minus the entire series) for stations with (blue) and without (grey) tropical-cyclone-induced record floods.

clones on the upper-tail properties of flood peak distributions. These stations are mainly located in inland regions of southern China. Our results are different from the study of Villarini and Smith (2010) in the eastern United States that shows significant decreases in shape parameters for the majority of stations when annual flood peaks caused by tropical cyclones are removed from the series. The differences are tied to contrasting flood-generation mechanisms between China and the eastern United States. Tropical cyclones and extratropical systems play central roles in the mixture of floodgeneration mechanisms for the flooding in the eastern United States (Smith et al., 2011). Extreme rainfall associated with East Asian summer monsoon, rather than landfalling tropical cyclones, can be a more important player in characterizing the upper tail of flood peak distributions in most inland regions of southern China (e.g., the middle and lower portion of the Yangtze River basin) (Zhang et al., 2017). Tropical cyclones in northern China, even though characterized by a low frequency of occurrence, pose significant influences on the upper-tail properties of flood peak distributions.

We focus on tropical cyclones that produced relatively large numbers of flood peaks over China, to shed light on the physical attributes of the most severe flood hazards associated with landfalling tropical cyclones. There are nine tropical cyclones that produced more than 100 annual flood peaks over China from the late 1950s to the present. The nine tropical cyclones alone contribute to approximately $50 \%$ of total annual flood peaks caused by tropical cyclones. Table 1

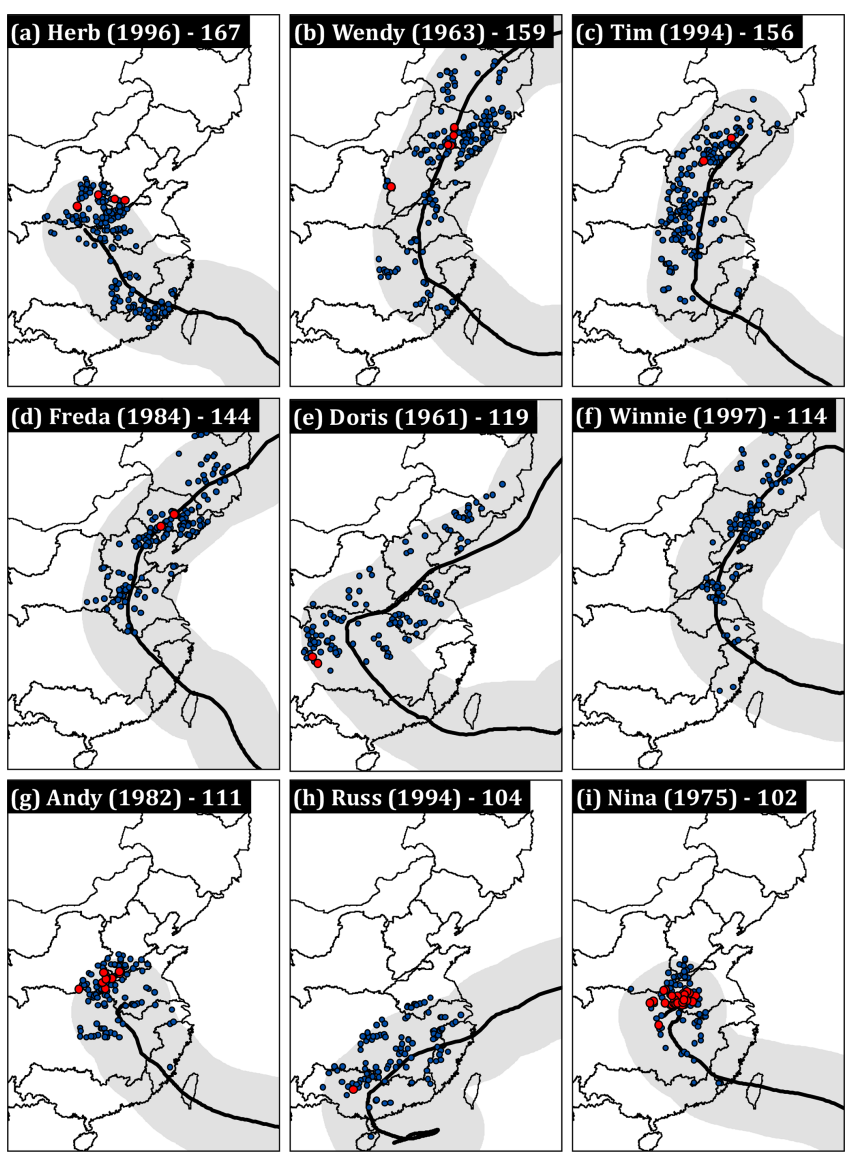

Figure 11. Tropical cyclones that produced more than 100 annual flood peaks (blue dots) over China. Red dots highlight that the annual flood peak is also the record flood of the station. Darkblack line shows tropical-cyclone track. Grey shading represents the $500 \mathrm{~km}$ buffer zone of each track. See Table 1 for more details.

provides a summary of the nine tropical cyclones. Typhoon Herb (1996) produced the largest number of annual flood peaks (167 in total), followed by Typhoon Wendy (1963) and Typhoon Tim (1994). Typhoon Herb (1996) produced a large number of annual flood peaks right after its landfall in mainland China (Fig. 11a). Almost all the annual flood peaks caused by other tropical cyclones are distributed over the most inland regions (Fig. 11). The percentage of stations with annual flood peaks caused by tropical cyclones relative to total storm-affected stations (i.e., located within a $500 \mathrm{~km}$ buffer zone of each tropical-cyclone track) varies between $14 \%$ (Typhoon Doris) and $35 \%$ (Typhoon Herb). Typhoon Andy (1982) and Typhoon Russ (1994) lead to annual flood peaks for more than $30 \%$ of the storm-affected stations (Table 1).

The nine tropical cyclones can be further categorized into two groups according to the nature of the storm and spatial patterns of their tracks. The first group includes Typhoon Herb (1996), Typhoon Andy (1982), and Typhoon Nina (1975). The three tropical cyclones did not experience 
Table 1. Summary of tropical cyclones that produced more than 100 annual flood peaks over China. All the stations that are located within the $500 \mathrm{~km}$ buffer zone of each tropical-cyclone track are counted. The "storm type" column shows whether the tropical cyclone experienced an extratropical transition (ET) or not (TS).

\begin{tabular}{llrrrr}
\hline Rank & Storm name & $\begin{array}{r}\text { Total no. } \\
\text { of storm-affected } \\
\text { stations }\end{array}$ & $\begin{array}{r}\text { Total no. } \\
\text { of annual flood } \\
\text { peaks }\end{array}$ & $\begin{array}{r}\text { No. of } \\
\text { record } \\
\text { floods }\end{array}$ & $\begin{array}{l}\text { Storm } \\
\text { type }\end{array}$ \\
\hline 1 & Herb (1996) & 465 & 167 & 4 & TS \\
2 & Wendy (1963) & 622 & 159 & 6 & ET \\
3 & Tim (1994) & 591 & 156 & 2 & ET \\
4 & Freda (1984) & 634 & 144 & 2 & ET \\
5 & Doris (1961) & 836 & 119 & 2 & ET \\
6 & Winnie (1997) & 482 & 114 & 0 & ET \\
7 & Andy (1982) & 375 & 111 & 10 & TS \\
8 & Russ (1994) & 330 & 104 & 1 & ET \\
9 & Nina (1975) & 441 & 102 & 24 & TS \\
\hline
\end{tabular}

an extratropical transition during the entire life cycle of the storms, and they are characterized by two landfalls (i.e., Taiwan and mainland China). The tracks of these three tropical cyclones do not fall into the prevailing tropical-cyclone tracks in the western North Pacific basin (Wu et al., 2005). Typhoon Nina (1995) produced the largest number of record floods (24 in total) among all of the historical tropical cyclones over China, followed by Typhoon Polly (1960) (14 in total) and Typhoon Andy (1982) (10 in total). Annual flood peaks and record floods caused by tropical cyclones in the first group are frequently observed in northern China (mainly the middle portion of the Yellow River and the upper Huai He basins). This region is characterized by complex terrain, i.e., Qinling and Taihang Mountains. Interactions of tropical cyclones with a regional topography can significantly enhance rainfall intensity through orographic lifting, as demonstrated by Typhoon Nina (1975). For instance, historical records of extreme rainfall (e.g., three-day rainfall accumulation exceeding $1000 \mathrm{~mm}$ ) from Typhoon Nina (1975) were observed in the windward topographic region (Yang et al., 2017). The other six tropical cyclones are categorized into the second group (Fig. 11). A common feature for the tropical cyclones in the second group is the extratropical transition process during the life cycle of the storms. Annual flood peaks are frequently observed after the extratropical transition process (see the curvatures of tropical-cyclone tracks in the latitudes around $30^{\circ}$ in Fig. 11), and they are frequently observed in northern China. Except for Typhoon Herb (1996), four of the top five of the largest number of annual flood peaks are caused by tropical cyclones with an extratropical transition.

There is no strong preference for the spatial distribution of annual flood peaks with respect to storm tracks (i.e., left or right of the track), even though the records floods caused by tropical cyclones tend to be frequently observed in the leftfront quadrant (typically the down-shear side) of the circulations. This is related to the preferable distribution of extreme tropical-cyclone rainfall, due to enhanced moisture conver- gence and updraft on the down-shear side of the circulation (e.g., Atallah et al., 2007; Shu et al., 2018).

\section{Summary and conclusions}

In this study, we examine flood peak distributions over China based on 1120 stream gauging stations with continuous records of annual maximum instantaneous discharge for more than 50 years. The principal findings of this study can be summarized as follows:

1. Of all the stations, $38 \%$ and $35 \%$ exhibit significant change points in mean and in variance, respectively. Change points tend to occur during the period 19802000, and they show strong a spatial concentration in the lower Yellow River, upper Huai He, Hai He, upper Yangtze, and Pearl River basins. Hydrological regimes in these regions demonstrate intensive anthropogenic influences, for instance, large hydropower generation dams, cascade construction of small-capacity reservoirs, transboundary water-transfer projects, soilwater conservation projects, and urbanization. There is a weak signal of climate impacts on the abrupt changes in annual flood series across China. Abrupt change is the dominant mode of violation of the stationary assumption for annual flood peaks over China.

2. Approximately $6 \%$ of the stations (69 in total) show significant linear trends in the annual flood peak series. Those stations with significant trends are uniformly distributed across the country, with 62 of them exhibiting significantly decreasing trends. The decreasing trends of flood peak magnitude in northern China may be at least partially tied to changes in extreme rainfall. Disconnections between changes in annual rainfall extremes and annual maximum floods are identified in southern China, and these highlight complex flood-generation 
processes across China. The dominance of decreasing trends in annual flood peak series indicates weakening tendencies of severe flood hazards (i.e., annual maximum floods) over China, even though flood-affected area and economic damage has been on the rise in recent decades (Kundzewicz et al., 2019). Future studies need to further examine changes in flood frequency for a complete assessment on flood hazards (based on the peaks-over-threshold flood series, similarly see, e.g., Mallakpour and Villarini, 2015).

3. We fit the GEV distribution for the stationary time series of annual flood peaks, and we examined the dependence of its parameters on drainage area. We find that the location and scale parameters are linearly scaled with drainage area in a log-log domain. There is only a weak tendency for the shape parameters to decrease as a function of drainage area. Our results highlight scaleindependent properties of upper tails of flood peaks. The relationships between GEV parameters and drainage area show strong spatial splits between northern and southern China, indicating that space-time rainfall organization is an important player in determining the upper-tail properties of flood peak distributions over China. Procedures for regional flood frequency analysis should explicitly address the spatial splits through considering spatial heterogeneity in flood hydroclimatology.

4. Flood-generation systems over China show a mixture of monsoons, tropical cyclones, and extratropical systems. Tropical cyclones play an important role in characterizing the spatiotemporal variability of flood peaks and the upper-tail properties of flood peak distributions over China. More than $50 \%$ of the annual flood peaks on the southeastern coast are caused by tropical cyclones. The percentage progressively decreases when we move further inland and to higher latitudes. Tropical cyclones lead to heavier tails of flood peak distributions (with larger shape parameters of the GEV distribution) in northern China. Those regions are characterized by record floods frequently associated with tropical cyclones, despite the fact that tropical cyclones make landfall relatively infrequently compared to southern China. Record floods in southern China are more frequently associated with monsoon-related extreme rainfall rather than landfalling tropical cyclones. We highlight the importance of considering the mixture of floodgeneration mechanisms in flood frequency analyses especially in northern China. Contrasting roles of tropical cyclones in flood peak distributions highlight the necessity of tailored procedures for flood-control practices and flood hazard assessment across China. For instance, landfalling tropical cyclones can be good candidates for PMP or PMF designs for drainage basins in northern rather than southern China.
5. Tropical cyclones play an important role in the most severe flood hazards in the history of China. There are nine tropical cyclones that produced more than 100 annual flood peaks over China, contributing to approximately $50 \%$ of the total annual flood peaks caused by all historical tropical cyclones. The large number of annual flood peaks is associated with extended spatial coverage of extreme rainfall after the storms go through the processes of extratropical transition. An additional feature for severe flood hazards is tied to the favorable synoptic set-up for persistent moisture transport after the storm makes landfall, as demonstrated by Typhoon Herb (1996), Typhoon Andy (1982), and Typhoon Nina (1975). Interaction of tropical cyclones with the regional topography is a key element for the most extreme floods in central China (mainly the middle or lower Yellow River basin and upper Huai He basin). Annual flood peaks caused by tropical cyclones do not show strong spatial preferences with respect to the tracks, even though the record floods tend to be frequently observed in the left-front quadrant of the circulation. Hydrometeorological analyses can provide improved physical characterization on severe flood hazards associated with landfalling tropical cyclones (see e.g., Yang et al., 2017).

Attribution analysis on the nonstationarities of annual flood peaks across China point to mixed controls of human activities, external climate factors (i.e., extreme rainfall), and changes in the soil moisture for flood hydrology. The homogeneity of the flood population for flood frequency analysis needs to be carefully revisited in a changing environment. This is especially proposed by England et al. (2018) in Hydrology Subcommittee Bulletin 17C as an imminent need to "define flood potentials for watersheds altered by urbanization, wildfires, deforestation, and by reservoirs". Innovative approaches that explicitly address the nonstationarities should be embraced for flood frequency analysis across China. These include process-based approaches that rely on physically based hydrological modeling which can represent the processes of nonstationarities in flood series (see e.g., Wright et al., 2014; Yu et al., 2019) and statistical-modeling approaches that mathematically parametrize the role of human regulations in flood series based on the framework of probability theory (Salas et al., 2018; Serago and Vogel, 2018; Gao et al., 2019; Dong et al., 2019; Barth et al., 2019). These approaches should be especially used in areas of northern China that exhibit an overwhelming portion of stations with nonstationarities in flood series.

Our results highlight the important role of landfalling tropical cyclones in determining the upper tails of flood peak distributions across China, especially northern China and the southeastern coast. Previous studies show strong teleconnections between tropical-cyclone activity in the western North Pacific basin and large-scale climate variability, e.g., the El 
Niño-Southern Oscillation (e.g., Chan and Shi, 1996; Chan, 2000) and Madden-Julian Oscillation (e.g., Kim et al., 2008). Statistical models that adopt varying parameters on time or other predictors (such as large-scale climate indices) can provide predictive tools of understanding future changes in flood hazards associated with landfalling tropical cyclones (e.g., Zhang et al., 2018c). Future studies need to zoom into watershed scales and explore physical connections between extreme-flood processes and key tropical-cyclone features (e.g., space-time structures of tropical-cyclone rainfall and tropical-cyclone intensity), to provide additional insights into flood hazards associated with landfalling tropical cyclones.

A unique feature of our study is a nationwide assessment of flood hazards based on an unprecedented network of stream gauging stations across China. Comprehensive analysis based on the exceptional dataset over China, together with studies by Villarini et al. (2009) and Burn and Whitfield (2018) in North America and Blöschl et al. (2017, 2019) in European countries, among others, promotes an improved understanding of flood hydrology and hydroclimatology under a changing environment from a global perspective. A future endeavor will further exploit the dataset through developing a data archive of key hydrological indices that is accessible to the worldwide research community (similarly see, e.g., Do et al., 2018).

Data availability. The data used in this research are collected from distributed hydrological offices of major river basins over China. The dataset is not available for public access at this time due to licensing issues.

Author contributions. LY designed the study and carried out the analysis. LY wrote the paper with contributions from LW. All authors contributed to the discussion and revision.

Competing interests. The authors declare that they have no conflict of interest.

Acknowledgements. This research is supported by the Strategic Priority Research Program of the Chinese Academy of Sciences (grant no. XDA23040202). Long Yang acknowledges support from the Natural Science Foundation of Jiangsu Province (grant no. BK 20190314). Xiang Li acknowledges support from the National Natural Science Foundation of China (grant no. 51609256) and the Young Elite Scientists Sponsorship Program of the China Association for Science and Technology (grant no. 2017QNRC001). The authors would like to acknowledge Gabriele Villarini from the University of Iowa and James Smith from Princeton University for prereview comments and Hong Do and the other anonymous reviewer for their review comments, which substantially improved the paper. The authors would like to extend sincere thanks to colleagues and collaborators from hydrographic offices of major river basins across China for their exceptional contribution to this dataset.
Financial support. This research has been supported by the Strategic Priority Research Program of the Chinese Academy of Sciences (grant no. XDA23040202), Natural Science Foundation of Jiangsu Province (grant no. BK 20190314), the National Science Foundation of China (grant no. 51609256), and the Young Elite Scientists Sponsorship Program of the China Association for Science and Technology (grant no. 2017QNRC001).

Review statement. This paper was edited by Xing Yuan and reviewed by Hong Do and one anonymous referee.

\section{References}

Arnell, N. W. and Gosling, S. N.: The impacts of climate change on river flood risk at the global scale, Climatic Change, 134, 387401, 2016.

Atallah, E., Bosart, L. F., and Aiyyer, A. R.: Precipitation distribution associated with landfalling tropical cyclones over the Eastern United States, Mon. Weather Rev., 135, 2185-2206, 2007.

Atallah, E. H. and Bosart, L. F.: The Extratropical Transition and precipitation distribution of Hurricane Floyd (1999), Mon. Weather Rev., 131, 1063-1081, 2003.

Ayalew, T. B., Krajewski, W. F., Mantilla, R., Wright, D. B., and Small, S. J.: Effect of spatially distributed small dams on flood frequency: insights from the Soap Creek watershed, J. Hydrol. Eng., 22, 04017011, https://doi.org/10.1061/(ASCE)HE.19435584.0001513, 2017.

Bai, P., Liu, X., Liang, K., and Liu, C.: Investigation of changes in the annual maximum flood in the Yellow River basin, China, Quaternary Int., 392, 168-177, 2016.

Barros, A. P., Duan, Y., Brun, J., and Medina, M. A.: Flood nonstationarity in the Southeast and Mid-Atlantic regions of the United States, J. Hydrol. Eng., 19, 05014014, https://doi.org/10.1061/(ASCE)HE.1943-5584.0000955, 2014.

Barth, N. A., Ph, D., Villarini, G., Ph, D., White, K., and Ph, D.: Accounting for Mixed Populations in Flood Frequency Analysis: Bulletin 17C Perspective, J. Hydrol. Eng., 24, 1-12, 2019.

Bates, N. S., Smith, J. A., and Villarini, G.: Flood response for the watersheds of the Fernow Experimental Forest in the central Appalachians, Water Resour. Res., 51, 4431-4453, 2015.

Berghuijs, W. R., Woods, R. A., Hutton, C. J., and Sivapalan, M.: Dominant flood generating mechanisms across the United States, Geophys. Res. Lett., 43, 4382-4390, 2016.

Blöschl, G., Hall, J., Parajka, J., Perdigão, R. A. P., Merz, B., Arheimer, B., Aronica, G. T., Bilibashi, A., Bonacci, O., Borga, M., Ivan, Č., Castellarin, A., and Chirico, G. B.: Changing climate shifts timing of European floods, Science, 357, 588-590, 2017.

Blöschl, G., Hall, J., Viglione, A., Perdigão, R., Parajka, R., Merz, B., Lun, D., Arheimer, B., Aronica, G., Bilibashi, A., Boháč, M., Bonacci, O., Borga, M., Čanjevac, I., Castellarin, A., Chirico, G., Claps, P., Frolova, N., Ganora, D., Gorbachova, L., Gül, A., Hannaford, J., Harrigan, S., Kireeva, M., Kiss, A., Kjeldsen, T., Kohnová, S., Koskela, J., Ledvinka, O., Macdonald, N., Mavrova-Guirguinova, M., Mediero, L., Merz, R., Molnar, P., Montanari, A., Murphy, C., Osuch, M., Ovcharuk, V., Radevski, I., Salinas, J., Sauquet, E., Šraj, M., Szolgay, J., Volpi, E., Wilson, 
D., Zaimi, K., and Živković, N.: Changing climate both increases and decreases European floods, Nature, 573, 108-111, 2019.

Brooks, F. and Day, C. A.: Analyzing the Mixed Flood Hydroclimatology of the Red River Basin, Kentucky, Journal of the Kentucky Academy of Science, 75, 47-52, 2015.

Burn, D. H. and Whitfield, P. H.: Changes in flood events inferred from centennial length streamflow data records, Adv. Water Resour., 121, 333-349, 2018.

Chan, J. C.: Tropical Cyclone Activity over the Western North Pacific Associated with El Niño and La Niña Events, J. Climate, 13, 2960-2972, 2000.

Chan, J. C. and Shi, J. E.: Long-term trends and interannual variability in tropical cyclone activity over the western North Pacific, Geophys. Res. Lett., 23, 2765-2767, 1996.

Cleveland, W.: Robust locally weighted regression and smoothing scatterplots, J. Am. Stat. Assoc., 74, 829-836, 1979.

Coles, S.: An introduction to statistical modeling of extreme values, Springer, London, 2001.

Costa, J. E.: A comparison of the largest rainfall-runoff floods in the United States with those of the People's Republic of China and the world, J. Hydrol., 96, 101-115, 1987.

Dankers, R., Arnell, N. W., Clark, D. B., Falloon, P. D., Fekete, B. M., Gosling, S. N., Heinke, J., Kim, H., Masaki, Y., Satoh, Y., Stacke, T., Wada, Y., and Wisser, D.: First look at changes in flood hazard in the Inter-Sectoral Impact Model Intercomparison Project ensemble, P. Natl. Acad. Sci. USA, 111, 3257-3261, 2014.

Ding, Y. and Chan, J. C. L.: The East Asian summer monsoon: an overview, Meteorol. Atmos. Phys., 89, 117-142, 2005.

Ding, Y. and Zhang, J.: Torrential Rains and Flashing Floods, Meteorological Press, Beijing, China, 2009

Do, H. X., Westra, S., and Leonard, M.: A global-scale investigation of trends in annual maximum streamflow, J. Hydrol., 552, 28-43, 2017.

Do, H. X., Gudmundsson, L., Leonard, M., and Westra, S.: The Global Streamflow Indices and Metadata Archive (GSIM) - Part 1: The production of a daily streamflow archive and metadata, Earth Syst. Sci. Data, 10, 765-785, https://doi.org/10.5194/essd10-765-2018, 2018.

Do, H. X., Zhao, F., Westra, S., Leonard, M., Gudmundsson, L., Chang, J., Ciais, P., Gerten, D., Gosling, S. N., Schmied, H. M., Stacke, T., Stanislas, B. J. E., and Wada, Y.: Historical and future changes in global flood magnitude - evidence from a model-observation investigation, Hydrol. Earth Syst. Sci. Discuss., https://doi.org/10.5194/hess-2019-388, in review, 2019.

Dong, Q., Zhang, X., Lall, U., Sang, Y.-F., and Xie, P.: An improved nonstationary model for flood frequency analysis and its implication to the Three Gorges Dam, China, Hydrolog. Sci. J., 64, 845855, https://doi.org/10.1080/02626667.2019.1596274, 2019.

Eden, J. M., Wolter, K., Otto, F. E. L., Harvey, H., Environ, A., and Lett, R.: Attribution of extreme rainfall from Hurricane Harvey, August 2017, Environ. Res. Lett., 13, 019501, https://doi.org/10.1088/1748-9326/aa9ef2, 2018.

England, J. F., Cohn, T. A., Faber, B. A., Stedinger, J. R., Thomas Jr., W. O., Veilleux, A. G., Kiang, J. E., and Mason Jr., R. R.: Guidelines for determining flood flow frequency - Bulletin 17C, Tech. rep., Reston, VA, https://doi.org/10.3133/tm4B5, 2018.

Enzel, Y., Ely, L. L., House, P. K., Baker, R., and Webb, R. H.: Paleoflood Evidence for a Natural Upper Bound to Flood Mag- nitudes in the Colorado River Basin basin, Water Resour. Res., 29, 2287-2297, 1993.

Franks, S. W. and Kuczera, G.: Flood frequency analysis: evidence and implications of secular climate variability, New South Wales, Water Resour. Res., 38, 1-7, 2002.

Gao, S., Liu, P., Pan, Z., Ming, B., Guo, S., Cheng, L., and Wang, J.: Incorporating reservoir impacts into flood frequency distribution functions, J. Hydrol., 568, 234-246, 2019.

Gaume, E.: Flood frequency analysis: The Bayesian choice, Wiley Interdisciplinary Reviews: Water, 5, e1290, https://doi.org/10.1002/wat2.1290, 2018.

Gu, X., Zhang, Q., Singh, V. P., Liu, L., and Shi, P.: Spatiotemporal patterns of annual and seasonal precipitation extreme distributions across China and potential impact of tropical cyclones, Int. J. Climatol., 37, 3949-3962, 2017a.

Gu, X., Zhang, Q., Singh, V. P., and Shi, P.: Nonstationarity in timing of extreme precipitation across China and impact of tropical cyclones, Global Planet. Change, 149, 153-165, $2017 \mathrm{~b}$.

Hart, R. E. and Evans, J. L.: A climatology of the extratropical transition of Atlantic tropical cyclones, J. Climate, 14, 546-564, 2000.

Held, I. M. and Soden, B. J.: Robust Responses of the Hydrological Cycle to Global Warming, J. Climate, 19, 1-14, 2006.

Hirabayashi, Y., Mahendran, R., Koirala, S., Konoshima, L., Yamazaki, D., Watanabe, S., Kim, H., and Kanae, S.: Global flood risk under climate change, Nat. Clim. Change, 3, 816-821, 2013.

Hirschboeck, K. K.: Flood hydroclimatology, in: Flood Geomorphology, edited by: Baker, V. R., Kockel, R. C., and Patton, P. C., John Wiley, New York, 27-49, 1988.

Hodgkins, G., Dudley, R., Archfield, S., and Renard, B.: Effects of climate, regulation, and urbanization on historical flood trends in the United States, J. Hydrol., 573, 697-709, 2019.

Houze, R.: Orographic Effects on Precipitating Clouds, Rev. Geophys., 50, 1-47, 2012.

Ishak, E. H., Rahman, A., Westra, S., Sharma, A., and Kuczera, G.: Evaluating the non-stationarity of Australian annual maximum flood, J. Hydrol., 494, 134-145, 2013.

Ivancic, T. J. and Shaw, S. B.: Examining why trends in very heavy precipitation should not be mistaken for trends in very high river discharge, Climatic Change, 133, 681-693, 2015.

Jarrett, R. D. and Costa, J. E.: Evaluation of the flood hydrology in the Colorado Front Range using precipitation, streamflow, and paleoflood data for the Big Thompson River basin, Tech. rep., https://doi.org/10.3133/wri874117, 1988.

Jiang, F. and Jiang, B.: Study on impacts of typhoon on China and its characteristics, Yangtze River, 45, 1-5, 2014.

Katz, R. W., Parlange, M. B., and Naveau, P.: Statistics of extremes in hydrology, Adv. Water Resour., 25, 1287-1304, 2002.

Kendall, M.: Rank correlation methods, Charlies Griffin, London, 1975.

Kim, J. H., Ho, C. H., Kim, H. S., Sui, C. H., and Park, S. K.: Systematic variation of summertime tropical cyclone activity in the western North Pacific in relation to the Madden-Julian oscillation, J. Climate, 21, 1171-1191, 2008.

Kundzewicz, Z., Su, B., Wang, Y., Xia, J., Huang, J., and Jiang, T.: Flood risk and its reduction in China, Adv. Water Resour., 130, 37-45, https://doi.org/10.1016/j.advwatres.2019.05.020, 2019.

Leonard, M., Westra, S., Phatak, A., Lambert, M., Hurk, B. V. D., Mcinnes, K., Risbey, J., Jakob, D., and Stafford-smith, M.: A 
compound event framework for understanding extreme impacts, WIREs Clim. Change, 5, 113-128, 2014.

Liu, M. and Smith, J. A.: Extreme rainfall from landfalling tropical cyclones in the Eastern United States: Hurricane Irene (2011), J. Hydrometeorol., 17, 2883-2904, 2016.

Liu, S., Huang, S., Xie, Y., Wang, H., Leng, G., Huang, Q., Wei, X., and Wang, L.: Identification of the Non-stationarity of Floods: Changing Patterns, Causes, and Implications, Water Resour. Manag., 33, 939-953, 2018.

Lu, W., Lei, H., Yang, D., Tang, L., and Miao, Q.: Quantifying the impacts of small dam construction on hydrological alterations in the Jiulong River basin of Southeast China, J. Hydrol., 567, 382392, 2018

Ma, S., Zhou, T., Dai, A., and Han, Z.: Observed changes in the distributions of daily precipitation frequency and amount over China from 1960 to 2013, J. Climate, 28, 6960-6978, 2015.

Mallakpour, I. and Villarini, G.: The changing nature of flooding across the central United States, Nat. Clim. Change, 5, 250-254, 2015.

Mann, H. B.: Nonparametric tests against trend, Econometrica, 13, 245-259, 1945.

Marvel, K. and Bonfils, C.: Identifying external influences on global precipitation, P. Natl. Acad. Sci. USA, 110, 19301-19306, 2013.

Matteson, D. S. and James, N. A.: A nonparametric approach for multiple change point analysis of multivariate data, J. Am. Stat. Assoc., 109, 334-345, 2014.

Mediero, L., Santillán, D., Garrote, L., and Granados, A.: Detection and attribution of trends in magnitude, frequency and timing of floods in Spain, J. Hydrol., 517, 1072-1088, 2014.

Milly, P. C. D., Wetherald, R. T., Dunne, K. A., and Delworth, T. L.: Increasing risk of great floods in a changing climate, Nature, 415 , 4-7, 2002.

Milly, P. C. D., Bentacourt, J., Falkenmark, M., Robert, M., Hirsch, R. M., Kundzewicz, Z. W., Letternmaier, D. P., and Stouffer, R. J.: Stationarity is dead: whither water management? , Science, 319, 573-574, 2008.

Montanari, A. and Koutsoyiannis, D.: Modeling andmitigating natural hazards: Stationarity is immortal!, Water Resour. Res., 50, 9748-9756, 2014.

Morrison, J. E. and Smith, J. A.: Stochastic modeling of flood peaks using the generalized extreme value distribution, Water Resour. Res., 38, 1305, https://doi.org/10.1029/2001WR000502, 2002.

O'Connor, J. E., Grant, G. E., and Costa, J. E.: The Geology and Geography of Floods, Ancient Floods Mod. Hazards, 5, 359-385, 2002.

Petrow, T. and Merz, B.: Trends in flood magnitude, frequency and seasonality in Germany in the period 1951-2002, J. Hydrol., 371, 129-141, 2009.

Pettitt, A. N.: A non-parametric approach to the change-point problem, Appl. Stat., 1, 126-135, 1979.

Rappaport, E. N.: Fatalities in the united states from atlantic tropical cyclones: New data and interpretation, B. Am. Meteorol. Soc., 95, 341-346, 2014.

Ren, F., Wu, G., Wang, X., and Wang, Y.: Changes in tropical cyclone precipitation over China, Indian Ocean Tropical Cyclones and Climate Change, 33, 25-28, 2010.

Rios Gaona, M. F., Villarini, G., Zhang, W., and Vecchi, G. A.: The added value of IMERG in characterizing rainfall in tropical cyclones, Atmos. Res., 209, 95-102, 2018.
Risser, M. D. and Wehner, M. F.: Attributable Human-Induced Changes in the Likelihood and Magnitude of the Observed Extreme Precipitation during Hurricane Harvey, Geophys. Res. Lett., 44, 12457-12464, 2017.

Robson, A. J.: Evidence for trends in UK flooding, Philos. T. Roy. Soc. A, 360, 1327-1343, 2002.

Robson, A. J., Jones, T. K., Reed, D. W., and Bayliss, A. C.: A study of national trend and variation in UK floods, Int. J. Climatol., 18, 165-182, 1998.

Salas, J. D., Obeysekera, J., and Vogel, R. M.: Techniques for assessing water infrastructure for nonstationary extreme events: a review, Hydrolog. Sci. J., 63, 325-352, 2018.

Schaller, N., Kay, A. L., Lamb, R., Massey, N. R., Van Oldenborgh, G. J., Otto, F. E., Sparrow, S. N., Vautard, R., Yiou, P., Ashpole, I., Bowery, A., Crooks, S. M., Haustein, K., Huntingford, C., Ingram, W. J., Jones, R. G., Legg, T., Miller, J., Skeggs, J., Wallom, D., Weisheimer, A., Wilson, S., Stott, P. A., and Allen, M. R.: Human influence on climate in the 2014 southern England winter floods and their impacts, Nat. Clim. Change, 6, 627-634, 2016.

Serago, J. M. and Vogel, R. M.: Parsimonious nonstationary flood frequency analysis, Adv. Water Resour., 112, 1-16, 2018.

Serinaldi, F. and Kilsby, C. G.: Rainfall extremes: Toward reconciliation after the battle of distributions, Water Resour. Res., 50, 336-352, 2014.

Sharma, A., Wasko, C., and Lettenmaier, D. P.: If Precipitation Extremes Are Increasing, Why Aren't Floods?, Water Resour. Res., 54, 8545-8551, 2018.

Shu, S., Feng, X., and Wang, Y.: Essential role of synoptic environment on rainfall distribution of landfalling tropical cyclones Over China, J. Geophys. Res.-Atmos., 123, 11285-11306, 2018.

Si, Y., Li, X., Yin, D., Li, T., and Cai, X.: PT State Key Laboratory of Simulation and Regulation of Water Cycle in River Basin, China Institute of, Sci. Total Environ., 682, 1-18, 2019.

Singh, V. P., Wang, S. X., and Zhang, L.: Frequency analysis of nonidentically distributed hydrologic flood data, J. Hydrol., 307, 175-195, 2005.

Small, D., Islam, S., and Vogel, R. M.: Trends in precipitation and streamflow in the eastern U.S.: Paradox or perception?, Geophys. Res. Lett., 33, 2-5, 2006.

Smith, J. A. and Baeck, M. L.: "Prophetic vision, vivid imagination": The 1927 Mississippi River flood, Water Resour. Res., 51, 9127-9140, 2015.

Smith, J. A., Baeck, M. L., Villarini, G., and Krajewski, W. F.: The hydrology and hydrometeorology of flooding in the Delaware River basin, J. Hydrometeorol., 11, 841-859, 2010.

Smith, J. A., Villarini, G., and Baeck, M. L.: Mixture distributions and the hydroclimatology of extreme rainfall and flooding in the Eastern United States, J. Hydrometeorol., 12, 294-309, 2011.

Smith, J. A., Cox, A. A., Baeck, M. L., Yang, L., and Bates, P.: Strange floods: the upper tail of flood peaks in the United States, Water Resour. Res., 54, 6510-6542, 2018.

Svensson, C. and Berndtsson, R.: Characterization of extreme rainfall in an East Asian monsoon-climate catchment in the upper reaches of the Huai River, China, Int. J. Climatol., 16, 321-337, 1996.

Tan, X. and Gan, T. Y.: Nonstationary analysis of annual maximum streamflow of Canada, J. Climate, 28, 1788-1805, 2014.

Trenberth, K. E., Fasullo, J. T., and Shepherd, T. G.: Attribution of climate extreme events, Nat. Clim. Change, 5, 725-730, 2015. 
Villarini, G.: On the seasonality of flooding across the continental United States, Adv. Water Resour., 87, 80-91, 2016.

Villarini, G. and Smith, J. A.: Flood peak distributions for the eastern United States, Water Resour. Res., 46, 1-17, 2010.

Villarini, G., Serinaldi, F., Smith, J. A., and Krajewski, W. F.: On the stationarity of annual flood peaks in the continental United States during the 20th century, Water Resour. Res., 45, 1-17, 2009.

Villarini, G., Smith, J. A., Serinaldi, F., and Ntelekos, A. A.: Analyses of seasonal and annual maximum daily discharge records for central Europe, J. Hydrol., 399, 299-312, 2011.

Villarini, G., Smith, J. A., Serinaldi, F., Ntelekos, A. A., and Schwarz, U.: Analyses of extreme flooding in Austria over the period 1951-2006, Int. J. Climatol., 32, 1178-1192, 2012.

Villarini, G., Goska, R., Smith, J. A., and Vecchi, G. A.: North atlantic tropical cyclones and U.S. flooding, B. Am. Meteorol. Soc., 95, 1381-1388, 2014.

Vogel, R. M., Yaindl, C., and Walter, M.: Nonstationarity: Flood magnification and recurrence reduction factors in the united states, J. Am. Water Resour. As., 47, 464-474, 2011.

Wasko, C. and Nathan, R.: Influence of changes in rainfall and soil moisture on trends in flooding, J. Hydrol., 575, 432-441, https://doi.org/10.1016/j.jhydrol.2019.05.054, 2019.

Wright, D. B., Smith, J. A., and Baeck, M. L.: Flood frequency analysis using radar rainfall fields and stochastic storm transposition, Water Resour. Res., 50, 191-203, 2014.

Wu, L., Wang, B., and Geng, S.: Growing typhoon influence on east Asia, Geophys. Res. Lett., 32, 1-4, 2005.

Yan, L., Xiong, L., Liu, D., Hu, T., and Xu, C.-Y.: Frequency analysis of nonstationary annual maximum fl ood series using the time-varying two-component mixture distributions, Hydrol. Process., 89, 69-89, 2017.

Yan, L., Xiong, L., Ruan, G., Xu, C.-Y., Yan, P., and Liu, P.: Reducing uncertainty of design floods of two-component mixture distributions by utilizing flood timescale to classify flood types in seasonally snow covered region, J. Hydrol., 574, 588-608, 2019.

Yang, L., Villarini, G., Smith, J. A., Tian, F., and Hu, H.: Changes in seasonal maximum daily precipitation in China over the period 1961-2006, Int. J. Climatol., 33, 1646-1657, 2013.

Yang, L., Liu, M., Smith, J. A., and Tian, F.: Typhoon Nina and the August 1975 Flood over Central China, J. Hydrometeorol., 18, 451-472, 2017.
Yang, T., Zhang, Q., Chen, Y. D., Tao, X., Xu, C.-Y., and Chen, X.: A spatial assessment of hydrologic alteration caused by dam construction in the middle and lower Yellow River, China, Hydrol. Process., 22, 3829-3843, 2008.

Yu, G., Wright, D. B., Zhu, Z., Smith, C., and Holman, K. D.: Process-based flood frequency analysis in an agricultural watershed exhibiting nonstationary flood seasonality, Hydrol. Earth Syst. Sci., 23, 2225-2243, https://doi.org/10.5194/hess-23-22252019, 2019.

Zhang, Q., Wu, L., and Liu, Q.: Tropical cyclone damages in China 1983-2006, B. Am. Meteorol. Soc., 90, 489-495, 2009.

Zhang, Q., Gu, X., Singh, V. P., Xiao, M., and Xu, C.-Y.: Stationarity of annual flood peaks during 1951-2010 in the Pearl River basin, China, J. Hydrol., 519, 3263-3274, 2014.

Zhang, Q., Gu, X., Singh, V. P., Xu, C.-y., Kong, D., and Xiao, M.: Homogenization of precipitation and flow regimes across China: Changing properties, causes and implications, J. Hydrol., 530, 462-475, 2015.

Zhang, Q., Gu, X., Singh, V. P., Sun, P., Chen, X., and Kong, D.: Magnitude, frequency and timing of floods in the Tarim River basin, China: changes, causes and implications, Global Planet. Change, 139, 44-55, 2016.

Zhang, Q., Zheng, Y., Singh, V. P., Luo, M., and Xie, Z.: Summer extreme precipitation in eastern China: mechanisms and impacts, J. Geophys. Res., 122, 2766-2778, 2017.

Zhang, Q., Gu, X., Li, J., Shi, P., and Singh, V. P.: The impact of tropical cyclones on extreme precipitation over coastal and Inland Areas of China and its association to ENSO, J. Climate, 31, 1865-1880, 2018a.

Zhang, Q., Gu, X., Singh, V. P., Shi, P., and Sun, P.: More frequent flooding? Changes in flood frequency in the Pearl River basin, China, since 1951 and over the past 1000 years, Hydrol. Earth Syst. Sci., 22, 2637-2653, https://doi.org/10.5194/hess-22-26372018, 2018 b.

Zhang, W., Villarini, G., Vecchi, G. A., and Smith, J. A.: Urbanization exacerbated the rainfall and flooding caused by hurricane Harvey in Houston, Nature, 563, 384-388, $2018 \mathrm{c}$. 